\title{
Modifying the Abridged Version of the Gross National Happiness Index Survey to Suit the Singapore Hospitality Industry
}

\author{
Godofredo Cristobal Utanes \\ SDH Institute-Vatel Singapore, Singapore \\ Email: utanesfred@gmail.com
}

How to cite this paper: Utanes, G.C. (2020) Modifying the Abridged Version of the Gross National Happiness Index Survey to Suit the Singapore Hospitality Industry. Open Access Library Journal, 7: e6615. https://doi.org/10.4236/oalib.1106615

Received: July 15, 2020

Accepted: August 14, 2020

Published: August 17, 2020

Copyright $\odot 2020$ by author(s) and Open Access Library Inc.

This work is licensed under the Creative Commons Attribution International License (CC BY 4.0).

http://creativecommons.org/licenses/by/4.0/ (c) (i) Open Access

\begin{abstract}
Bhutan as a tourist destination intrigues many in the most part due to its very unique way of measuring its nation's success. While most countries in the world monitor their respective gross domestic products (GDPs) as the indicator of economic standing, for five decades the Bhutanese government and its people have maintained a different mindset. And they are firm and very proud of it. The Gross National Happiness (GNH) index was first conceptualised in Bhutan in the 70's. It is a measure of overall wellbeing and perceived by its advocates as the better success indicator of a country. Thanks to the inspiration of His Majesty the third Druk Gyalpo Jigme Dorji Wangchuck who addressed the United Nations in 1971, Bhutan ever since remained steadfast in the concept of GNH (Tourism Council of Bhutan, n.d.) [1]. This research is the first of its kind in Singapore. It is an attempt to apply the GNH index not to a country but to an industry, the hospitality industry in Singapore. It is a common observance in hotels and restaurants in many countries that staff experience stress and pressure. O'Neill and Davis (2011) [2] argued that employee stress is a major issue in the hospitality industry and claimed that it is costly to both employees and employers. As such, many find working in the hospitality field to be far from a walk in the park, so to speak. Veenhoven (2004) [3] pointed out "happiness" as interchangeable to "quality of life". It is worthwhile therefore to explore the effects of this highly challenging environment to the happiness and wellbeing of those who work there. Would this have impact on employee turnover and labour participation in this industry? This is a good question to answer in future studies. Thus, investigating the current condition of the industry particularly in a fast-paced work milieu like Singapore could trace the possible root causes of the manpower crunch being experienced at the time of this writing. The researcher examined the abridged version of the GNH (The Gross National Happiness Abridged Survey, 2011)
\end{abstract}


[4]. The objectives pursued in this investigation were: assess the suitability of the abridged GNH version in Singapore's hospitality industry, examine the possible amendments or changes that need to be done on the abridged GNH version to suit Singapore's hospitality sector, justify the changes on the abridged GNH version to suit Singapore's hospitality industry, and create the adapted version of the abridged GNH index suitable to Singapore's hospitality industry. As hypothesized, there are a significant number of changes that were needed to be done in the original abridged GNH version. Amendments were done that resulted in an adapted and modified version of the original abridged form. This modified abridged GNH version has been justified in this paper to be suitable for further studies to measure the happiness of workers in Singapore's hospitality industry (coined here as the GAS-SHI for Gross National Happiness Abridged Survey for the Singapore Hospitality Industry). The GAS-SHI could be used by policy makers in hospitality organisations and the Singapore government to measure and possibly improve hospitality worker's wellbeing.

\section{Subject Areas}

Human Resource Management

\section{Keywords}

Gross National Happiness, GNH Abridged Survey, Hospitality, Singapore

\section{Introduction}

In an attempt to apply the GNH survey in the Singapore hospitality sector, the researcher of this study deemed it necessary to assess the adaptability of the GNH index survey and will use the acronym GAS to stand for Gross National Happiness Abridged Survey from hereon. Pennock and Ura (2011) [5] had revised the robust original version consisting of 245 questions classified into 10 categories, namely: demographics, psychological wellbeing, health, time use and balance, education, cultural diversity and resilience, good governance, community vitality, environment, and living standards (the second GNH, 2010) [6]. As such, it had been called as the GNH abridged survey consisting eventually of 320 variables in 163 questions categorised into 11 domains, namely: demographics and household, happiness and wellbeing, health, family and community, time use and balance, education, core values, cultural vitality, governance, your environment, and living standards. This abridged version was later used in other countries outside Bhutan.

The GNH tried to explore the multidimensional nature of happiness (Pennock and Ura, 2011) [5]. One of the most interesting territories of this vital emotional milieu can explore is the service sector, specifically the hospitality industry. In Singapore, this study is considered pioneering and perhaps even in Asia. Hadee (2015) [7] reported that according to the Ministry of Manpower in Singapore 
that the service sector's average monthly resignation rate in 2015 was $2.6 \%$. This was high compared to the overall rate at $1.9 \%$ across various local industries nationwide in the same year (Summary table: Labour Turnover, 2017) [8]. Quek (May 30, 2017) lamented the frustrating lack of manpower in the Singapore hotel and restaurant businesses. Gupta (as cited in Quek, 2017) mentioned that one of the reasons why Singapore's hospitality sector is in a protracted agony over manpower shortage is the lack of motivated staff.

At the backdrop of Singapore's ironic labour issues despite the numerous foreign workers want to be employed in Singapore but are hindered by local government's related undisclosed political and economic directions, it is fitting to adopt an instrument that would take a closer look at the possible influence or correlation if needed, if there are, on Singapore's hospitality workers' "happiness" temperature and the probable variables around it. The GAS therefore is a tool that could serve as a starting point to facilitate this objective. However, due to the scarcity of precedent researches of this nature, this particular study will not only be pioneering in Singapore but also primitive at the same time. Nonetheless, the parallel conditions of countries with industries revolving around the facets of emotional, mental, and psychological life elements, among other regimes, could work in favour of this investigative undertaking.

\section{Review of Related Literature}

A few researches were conducted and articles were about the wellbeing of hospitality and services staff in Singapore as well as the Singapore populace in general (Wong, 2018 [9]; Lai, 2017 [10]; How to Measure Well-Being, 2017 [11]). There is, however, no study that has ever been undertaken to explore whether hospitality staff are happy about their work and social life in this setting. Thus, it goes without saying that the GNH index survey has not ever been tested among workers in Singapore's accommodation industry that currently numbers more than 400 around the small island.

The GNH survey (Bhutan Living Standards Survey, 2013) [12], its abridged version (Pennock and Ura, 2011) [5], and similar wellbeing indexes have been used in certain countries outside Bhutan in an attempt to measure the wellbeing of people in those countries. Later, Brazil and Canada were among those that started adopting the GNH index (Briney, 2017) [13]. In 2011, Isabel Sebastian did a case study of travel and hotel companies whereby the concept of the GNH was applied in business (University of Technology Sydney, 2017) [14]. In the Netherlands, through an index, Boelhouver and van Campen (2013) [15] attempted to answer if the Dutch are a happy people. They concluded that a happiness policy is already imbedded in the Dutch society and that mental resilience emerges as essential factor in improving happiness.

In another study, Brooks (2008) [16] reviewed a book written by Arthur C. Brooks on Gross National Happiness and offered a comprehensive evidence regarding America's development and experience of "happiness". In yet another 
similar study, Tiefenback and Kohlbacker (2015) [17] used the National Survey on Lifestyle Preferences to measure happiness in Japan in times of crisis, specifically the March 11, 2011, earthquake that caused great tsunamis in the Fukushima prefecture. Using the index, the author concluded, among others, that there was a nationwide drop in happiness in Japan after that disaster. Tiwari and Mutascu (2015) [18] hypothesized that the GDP (Gross Domestic Product) and environmental degradation among 23 countries could be related to people's happiness. The author found out that GDP or the combined influence of GDP and environmental degradation are not related to happiness.

Like these studies, this present research explored the use of a happiness index. The author chose the GNH that originated from Bhutan, specifically the shorter abridged version. But unlike the above studies, this research paper applies to the hospitality industry in Singapore, a more specific set of target informants rather than the previous related studies' country horizons. It is noteworthy that GNH studies tend to be exhaustive and comprehensive. Following this tact, such limitation scoped out the inclusion of the actual application of the GNH, albeit, the modified abridged version that this present author designed, or redesigned, to suit the hospitality industry in Singapore. Rather, this study focused on the adaptation of the abridged version of the GNH with certain modifications. These changes are therefore justified in the succeeding sections.

In an online survey administered between July and August of 2017, Wong (2018) [9] reported that according to JobStreet.com's job happiness index in 2017, 45 percent of the Singapore workforce is not happy at work. The remaining proportions are either happy or answered neutral about being happy at work. As expatiated in the preliminary discourse, the dire need to improve the wellbeing of Singapore's services and hospitality workers remains the driver to investigate the suitability of the abridged GNH version (Pennock and Ura, 2011 [5]; Wong, 2018 [9]; Blackman, O’Flynn, and Mishra, 2010 [19]) particularly in Singapore's hospitality industry.

\section{Research Objectives}

The GNH index survey as evidenced in its original study in Bhutan as well as in a few other countries became a popular gauge of wellbeing. The results of utilizing this index in measuring people's happiness are reasonably convincing. This study therefore presumes that there is no further research to be done to qualify the use the GNH index survey, at its abridged version (Pennock and Ura, 2011) [5], to measure human wellbeing. However, there is the possibility of making revisions on this index. Thus, the following research objectives were formulated:

1) To assess the suitability of the abridged GNH version in Singapore's hospitality industry,

2) To examine the possible amendments or changes that need to be done on the abridged GNH version to suit Singapore's hospitality sector,

3) To justify the changes on the abridged GNH version to suit Singapore's 
hospitality industry, and

4) To create the adapted version of the abridged GNH index suitable to Singapore's hospitality industry.

\section{Methodology}

The temptation to use the 163 questions of the GNH abridged survey was overcome by scrutinizing each and every question item. The researcher of this present study evaluated the validity of each question for the purpose of the local hospitality industry. Conducting this analysis, the need to modify and possibly eliminate some of the question items were an outcome of extensive question item analysis and getting the assistance of hospitality students at the master level of SDH Institute (sdh.edu.sg) of Vatel Singapore (vatel.sg).

The survey questionnaire was tailored to suit the target respondents in the hospitality sector. This was done by allowing pre-master students individually and as groups to formulate alterations in the survey. Thereafter, the researcher filtered the versions derived from these students' works resulting in a further revised version.

To culminate the process, the researcher conducted a pilot test of the updated survey among a different cohort of students undertaking hospitality and tourism academic programmes. These nine (9) students were taking the Vatel Singapore's MBA International Hotel Management at that time. It was the researcher's belief that this batch of informants was appropriate considering many of them had either served as interns or were former employees in hotels, food and beverage outfits, and tourist destinations. This was besides their in-person industry exposure in their academic programme as well as practicum activities in Singapore's hospitality establishments. The final form of the survey had then been finalised after that test survey. This paper highlights the revisions and justifications for the itemized changes. The eventual resulting version may be used in further studies to conduct actual GNH studies focusing on industry professionals as respondents.

\section{The Modifications}

The pioneering GAS-SHI survey form (coined by this present researcher which stands for Gross National Happiness Abridged Survey for the Singapore Hospitality Industry) that came out from this present investigation required 93 alterations from the 320 variables of the GAS version by Pennock and Ura. This translates to $29 \%$ of the latter that needed to be modified to be deemed adaptable to the Singapore hospitality industry. Following are the specific modifications along with their respective reasons or justifications for the changes.

Educational attainment

Question Items 4 and 5 of the GNH abridged survey (GAS) separated the educational attainment between pre-post-secondary and post-secondary levels. The living standards survey conducted in Bhutan in 2012 reported that only 
7.8\% of all Bhutanese population attended formal education beyond Grade 12 . In the same report, $32 \%$ attended formal primary and secondary schools while the majority of the country's 753,000 people did not attend formal education (Living Standards Survey: Bhutan 2012, 2013) [12].

In Singapore's hospitality labour sector, for this matter, the total labour force in Singapore in 2016 reached 3.7 million with a 68\% labour force participation rate. Only $35.3 \%$ attended formal education below post-secondary schools. Thus, most of the labour population attended post-secondary, diploma, and degree education, i.e., 64.7\% (Total Foreign Worker Numbers, 2017) [20]. This evidently is significantly distant from the educational demography in Bhutan. It goes without saying therefore that if one has to adapt the GNH survey to the Singapore hospitality sector, it should take this into account and therefore the appropriate revision in the as mentioned is a must, i.e., totally deleting the question item on pre-post-secondary attainment.

Envy-Jealousy

The GAS Question Item 33 included two emotion answers under the moods/emotion variable, namely: "envy" and "jealousy". These two responses are unquestionably redundant and therefore needed to be addressed to maximise the efficacy of the research regimen. It was deemed by these researcher (GAS-SHI) adapting the GAS to the Singapore hospitality industry, at least one of these should be replaced. Consequently, "envy" was replaced by another emotion response that was not in the GAS Question Item 33 moods/emotions list, i.e., "hatred".

Bad-to-good response scale

The GAS-SHI researcher finds it necessary to revise the of the Likert scale responses of 65 variable-question items from good to bad mostly into bad to good. For example, for GAS Question Item 46, to wit:

"46. In general, would you say health is: Excellent/Very Good, Good, Fair/Poor?"

The GAS-SHI changed the alternative responses to: "Fair/Poor, Good, Excellent/Very Good" instead, the justification being that to make it more convenient for respondents to maintain a consistent train of thought. In turn, this move strengthens the reliability of the responses. More specifically, a weakness of the GAS related to this question item is that the responses shift from good-to-bad scale to bad-to-good scale then again to good-to-bad in the series of variable-question items throughout the survey. This poses an irregular response mindset that is subject to human errors.

The GAS question items that had been changed due to the above justification are Question Items 46, 57 - 70, 76, 80, 90 - 93, 95 (sub-items 1 through 24), 98 $101,103,105,110,112,119-123,125,130-134$, and $149-152$. As observed in the GAS, the question items in-between these ones follow the opposite order of scale responses. To reiterate, as the questions are extremely numerous, the respondents' tendency would be to commit possible mistakes such as that he might 
be referring to a positive response rather than a negative one as their subconscious thoughts and the propensity to speed-up completing the long survey would have been accustomed to the scale order that would have often appeared in the process. In effect, the revised order could minimise wrong responses and therefore increases the reliability and dependability of the survey (Brown, 1997) [21].

Deleting the "Don't Know" Response

In many parts of the GAS survey, there is the "Don't Know" answer. There are more than 70 variable-question items or $22 \%$ of the total number of question items with this enticingly convenient answer.

While the GAS-SHI researcher believed that the "Don't Know" response is necessary in some inquiries, it is undoubtedly not in many cases. For example, in GAS Question Item 152 with the question, "In the next two years, do you think your financial situation will get better, worse, or stay the same?" requires the "Don't Know" option. But this is not the case in many question items. Examples where this reply is not necessary but had been questionably included are as follows:

“GAS Question Item 34: Been able to concentrate on what you're doing.

More Than Usual | Same As Usual | Less Than Usual | Much Less Usual |

Don't Know"

and yet another:

“GAS Question Item 44: Been thinking of yourself as a worthless person.

Not At All | No More Than Usual | Rather Than Usual | Much More Than

Usual | Don't Know"

In these two question items, along with many others, the "Don't Know" answer is deemed illogical and unnecessary because it just elicits the undesired not-known data, weakening data quality. For many Singapore-based hospitality workers, though some question items might be inconvenient to answer, it is not impossible to choose the non-Don't Know option.

The following items whereby the "Don't Know" answer option is rather unwanted for adaptation of the GNH survey to the Singapore hospitality sector are as follows: GAS Question Items 27, 28, 34 - 45, 56 - 70, 78 - 80, 90 - 99, 130 - 138, and 148. The question items that have the "Don't Know" answer but are not listed here are left unchanged because they are considered mandatory, logical and genuinely convenient in order to achieve this research's reliability objective.

In addition, the GAS question item that needs to have the "Don't Know" answer but does not have it is only one, to wit: " 139 . What kind of biodiversity species have you noticed declining around your region?"

In this question item, hospitality workers in Singapore may not care about biodiversity or many not even know what it is.

Activity: Enjoyment

GAS Question Items 88 and 89 are in inconveniently fused together. Moreover, the alternative responses are presented as legends to accompany the actual question items. See below Table 1 . 
Table 1. GAS Question Items 88 and 89.

\begin{tabular}{|c|c|c|}
\hline & $\begin{array}{l}88 . \text { How much do you usually } \\
\text { enjoy these activities? } \\
1=\text { A lot } \\
2=\text { Somewhat } \\
3=\text { Did not enjoy } \\
9=\text { Do not perform this activity }\end{array}$ & $\begin{array}{l}\text { 87. Based on how you would like } \\
\text { to spend your time, do you } \\
\text { currently spend too much, not } \\
\text { enough or about the right amount } \\
\text { of time on each of the following } \\
\text { activities? } \\
1=\text { Too Much } \\
2=\text { About the Right Amount } \\
3 \text { = Not Enough }\end{array}$ \\
\hline & Insert Code From Above & Insert Code From Above \\
\hline Working at your job & TU22 & TU43 \\
\hline Taking care of or playing with children at home & TU23 & TU44 \\
\hline Providing extra care or assistance to sick or elderly persons in your home & TU24 & TU45 \\
\hline Shopping & TU25 & TU46 \\
\hline Preparing food & TU26 & TU47 \\
\hline Eating & TU27 & TU48 \\
\hline Doing housework, home maintenance or other chores for your household & TU28 & TU49 \\
\hline Participating in sports or hobbies & TU29 & TU50 \\
\hline Visiting/socialising with friends or neighbours & TU30 & TU51 \\
\hline Visiting/socialising with family members & TU31 & TU52 \\
\hline Reading & TU32 & TU53 \\
\hline Relaxing & TU33 & TU54 \\
\hline Praying/worshipping/meditating & TU34 & TU55 \\
\hline Watching TV, listening to the radio & TU35 & TU56 \\
\hline Using computer (outside of work), playing computer/video games & TU36 & TU57 \\
\hline Participating in voluntary activities & TU37 & TU58 \\
\hline Participating in religious activities & TU38 & TU59 \\
\hline Participating in political activities, visiting government offices & TU39 & TU60 \\
\hline Community activities (labour, meetings, etc.) & TU40 & TU61 \\
\hline Educational courses/activities & TU41 & TU62 \\
\hline Others, specify & TU42 & TU63 \\
\hline
\end{tabular}

Whether the survey would be conducted by way of face-to-face interview or self-administered, using the above format would create some confusion more than a more improved version and therefore inconvenience on the part of the interviewer and the interviewee or to the respondent if self-administered, respectively.

Hence, the GAS-SHI researcher split this question item set to address the possible confusion in order to adapt to the prospective hospitality-based respondents in Singapore, especially. See Table 2 below. To confirm this thinking, this study's researcher conducted a quick survey among a cohort of nine masters students in international hotel industry. Showing both the original version of the 
above two question items (Table 1) as well as the revised version (Table 2 below) to these students, the question was asked on which of the two versions is better. All the nine respondents unanimously agreed that the later version (Table 2 below) is simpler and easier to understand than the original one.

Another point to note in this revised question set is that the scale response order was changed from good-to-bad to bad-to-good in order to be consistent with most of the other question items requiring scale responses. Lastly, the alternate response, "Don't do this" is included to benefit those respondents who do not do any of these activities. Not providing this option as in the GAS makes it significantly more difficult for the respondent to decide on his or her answer. And this is the factual, humane reality that had been missed in the GAS.

Table 2. GAS-SHI Question Items 86 and 87.

86. How much do you usually enjoy these activities?

\begin{tabular}{|c|c|c|c|c|c|}
\hline & & 1 & 2 & 3 & 9 \\
\hline & & $\begin{array}{c}\text { Do not } \\
\text { enjoy }\end{array}$ & Somewhat & A lot & $\begin{array}{l}\text { Don't do } \\
\text { this }\end{array}$ \\
\hline $86 a$. & Working at your job & & & & \\
\hline $86 \mathrm{~b}$. & Taking care of or playing with children at home & & & & \\
\hline $86 c$ & $\begin{array}{l}\text { Providing extra care or assistance to sick or elderly } \\
\text { persons in your home }\end{array}$ & & & & \\
\hline $86 \mathrm{~d}$. & Shopping & & & & \\
\hline $86 \mathrm{e}$ & Preparing food & & & & \\
\hline $86 f$. & Eating & & & & \\
\hline $86 \mathrm{~g}$ & $\begin{array}{l}\text { Doing housework, home maintenance or other } \\
\text { chores for your household }\end{array}$ & & & & \\
\hline $86 h$. & Participating in sports or hobbies & & & & \\
\hline $86 \mathrm{i}$ & Visiting/socialising with friends or neighbours & & & & \\
\hline $86 j$. & Visiting/socialising with family members & & & & \\
\hline $86 \mathrm{k}$ & Reading & & & & \\
\hline 861. & Relaxing & & & & \\
\hline $86 \mathrm{~m}$. & Praying/worshipping/meditating & & & & \\
\hline $86 n$ & Watching $\mathrm{TV}$, listening to the radio & & & & \\
\hline 860. & $\begin{array}{l}\text { Using computer (outside of work), playing } \\
\text { computer/video games }\end{array}$ & & & & \\
\hline $86 \mathrm{p}$ & Participating in voluntary activities & & & & \\
\hline $86 \mathrm{q}$ & Participating in religious activities & & & & \\
\hline $86 r$ & $\begin{array}{l}\text { Participating in political activities, visiting } \\
\text { government offices }\end{array}$ & & & & \\
\hline $86 s$. & Community activities (labour, meetings, etc.) & & & & \\
\hline $86 \mathrm{t}$ & Educational courses/activities & & & & \\
\hline 86u. & Others, specify & & & & \\
\hline
\end{tabular}


87. Based on how you would like to spend your time, do you currently spend too much, not enough or about the right amount of time on each of the following activities?

\begin{tabular}{|c|c|c|c|c|}
\hline & & 1 & 2 & 3 \\
\hline & & Not enough & $\begin{array}{l}\text { About the } \\
\text { right amount }\end{array}$ & Too much \\
\hline $87 a$. & Working at your job & & & \\
\hline $87 \mathrm{~b}$. & Taking care of or playing with children at home & & & \\
\hline $87 \mathrm{c}$ & $\begin{array}{l}\text { Providing extra care or assistance to sick or } \\
\text { elderly persons in your home }\end{array}$ & & & \\
\hline $87 \mathrm{~d}$ & Shopping & & & \\
\hline $87 \mathrm{e}$ & Preparing food & & & \\
\hline $87 \mathrm{f}$ & Eating & & & \\
\hline $87 \mathrm{~g}$ & $\begin{array}{l}\text { Doing housework, home maintenance or other } \\
\text { chores for your household }\end{array}$ & & & \\
\hline $87 \mathrm{~h}$. & Participating in sports or hobbies & & & \\
\hline $87 \mathrm{i}$ & Visiting/socialising with friends or neighbours & & & \\
\hline $87 \mathrm{j}$. & Visiting/socialising with family members & & & \\
\hline $87 \mathrm{k}$. & Reading & & & \\
\hline 871. & Relaxing & & & \\
\hline $87 \mathrm{~m}$. & Praying/worshipping/meditating & & & \\
\hline $87 n$. & Watching TV, listening to the radio & & & \\
\hline $87 \mathrm{o}$ & $\begin{array}{l}\text { Using computer (outside of work), playing } \\
\text { computer/video games }\end{array}$ & & & \\
\hline $87 \mathrm{p}$ & Participating in voluntary activities & & & \\
\hline $87 \mathrm{q}$ & Participating in religious activities & & & \\
\hline $87 \mathrm{r}$ & $\begin{array}{l}\text { Participating in political activities, visiting } \\
\text { government offices }\end{array}$ & & & \\
\hline $87 \mathrm{~s}$ & Community activities (labour, meetings, etc.) & & & \\
\hline $87 \mathrm{t}$ & Educational courses/activities & & & \\
\hline $87 \mathrm{u}$ & Others, specify & & & \\
\hline
\end{tabular}

\section{Language Understanding and Spoken}

GAS Question Item 112 that asks, "Can you still understand this language?" is a generally unnecessary question for Singapore hoteliers and those serving in the tourism and restaurant sectors.

Analysing the respondent set in Bhutan, the GAS considered that there are 19 dialects spoken in the country where Dongkha is the main language spoken by only $28 \%$ of the population (Tourism Council, n.d. [22]; Gutman and Avanzati, 2014 [23]). Two languages Monkha and Gongduepkha are going extinct. It was in this context that the GAS question items on language under the cultural vitality dimension were constructed.

In Singapore, however, whether in the hospitality sector or any industry for 
that matter, workers commonly speak only few languages. The single mostly used is of course, the English language. Others are Mandarin, Malay, Tamil, and Filipino (Straits Times, March 10, 2016 [24]; Quora, July 14, 2016 [25]). In view of this, GAS Question Item 112 is irrelevant if it were to be used in the Singapore hospitality context. See the revised section in Table 3 below.

Table 3. GAS Question Items 111 to 117.

111. What was the language that you first learned at home in childhood?

\begin{tabular}{ccc}
\hline Lang 1 & Record Respondent's Answer & Enter Code \\
& \} & \} \\
\hline
\end{tabular}

112. Can you still understand this language?

Lang 2

\begin{tabular}{cc} 
Yes & No \\
\hline $\mathbf{1}$ & $\mathbf{2}$
\end{tabular}

If Not Go To

113. On a scale of 1 to 5 where 1 is not well at all and 5 is very well, how well can you understand this language now?

\begin{tabular}{cccccc}
\hline Lang 3 & Not Well At All & & \multicolumn{2}{c}{ Very Well } \\
& 1 & 2 & 3 & 4 & 5 \\
\hline
\end{tabular}

114. What language do you speak with most often at home?

Lang 4

Record Respondent's Answer

Enter Code

\}

115. What language do your speak most often with your friends?

\begin{tabular}{ccc}
\hline Lang 5 & Record Respondent's Answer & Enter Code \\
& \} & \} \\
\hline
\end{tabular}

116. Until the age of fifteen, what language did you and your parents use most of the time when speaking to each other?

\begin{tabular}{ccc}
\hline & Record Respondent's Answer & Enter Code \\
Lang 6 & \} & \} \\
\hline
\end{tabular}

117. Until you were fifteen, what language did you and your brothers, sisters and any other children in your household used most of the time when speaking to each other?

$\begin{array}{cc}\text { Lang } 7 & \text { Record Respondent's Answer } \\ \} & \text { Enter Code } \\ \end{array}$


Table 4. GAS-SHI Question Items 113 to 118

113. What was the language that you first learned at home in childhood?

114. How well can you understand that language now?

\begin{tabular}{cllcc}
\hline 1 & 2 & 3 & 4 & 5 \\
\hline Not well at all & & Very well \\
\hline
\end{tabular}

115. What language do you speak most often at home now?

116. What language do you speak with your friends now?

117. Since the time you came to this country, how often did you feel others did not treat you fairly because of your gender?

\begin{tabular}{ccccc}
\hline 1 & 2 & 3 & 4 & 5 \\
\hline Never & Rarely & Sometimes & Most of the time & All the time \\
\hline
\end{tabular}

118. At work, how often did you feel others did not treat you fairly because of your gender?

\begin{tabular}{ccccc}
\hline 1 & 2 & 3 & 4 & 5 \\
\hline Never & Rarely & Sometimes & Most of the time & All the time \\
\hline
\end{tabular}

Notice also that GAS Items 116 and 117 had been deleted, the ones indicating the respondent's age of fifteen. It is considered irrelevant by the GAS-SHI researcher. While they are relevant in Bhutan, it is not the case in the Singapore's hospitality sector study. See Table 4 above.

Discrimination

The word, "discrimination" in GAS Question Item 118 is deleted in the GAS-SHI version because this is a very sensitive issue in Singapore where multi-racial harmony is a major political and societal agenda. Sim (2015) [26] reported that then Minister for Culture, Community and Youth, Ms Grace Fu, signed a global agreement to eliminate discrimination based on race, colour, descent, nationality or ethnic origin. The minister emphasised that "discrimination has no place in Singapore".

Wang (2017) [27] noted that racial discrimination is illegal in Singapore. Moreover, he noted a controversial altercation between a local and a foreigner who exchanged accusations with a racial tone right in Singapore soil. Allegedly, it was brought about by the Singaporean's negative reaction against the foreigner's unique gesture of greeting a relative in Changi Airport upon arrival. This case became viral.

\section{Enough Money}

For the purpose of the Singapore hospitality sector, GAS Question Item 140, "Have you enough money to meet your needs?" is deemed unnecessary by the GAS-SHI researcher. This is because it is a redundant question as the answer could be inferred from those questions items succeeding this question item. 
Also, the researcher finds it another sensitive question because it is too direct to ask anybody regardless of nationality and culture.

\section{Living Standards}

GAS Question Item 143 is another question that requires improvement. The GAS-SHI researcher decided to revise it instead. Thus, instead of asking, "How often did this happen-almost once a month, some months but not every month, or in only one or two months?" referring to the previous query about not having food for a whole day because there was not enough money for food, the revised one reads as in Table 5 .

In Bhutan, it might be common that people go hungry. However, in Singapore, as long as one works like in the hospitality sector, nobody goes hungry. In this connection, in the revised survey question, the option, "Never" was included. See table below. GAS Question Item 146 had been deleted because it is exactly the same as GAS Question Item 143.

Table 5. GAS-SHI Question Item 141.

141. "How often did this happen?

\begin{tabular}{cccc}
\hline 1 & 2 & 3 & 9 \\
\hline Almost every month & $\begin{array}{c}\text { Some months but not every } \\
\text { month }\end{array}$ & Only one or two months & Never \\
\hline
\end{tabular}

Based on the researcher's experiences in doing research, GAS Question Item 147, "What was the approximate total cash income for your household during the past 12 months" that asks about salaries is another sensitive matter. For the Singapore hospitality sector, if it takes this form, chances are that responses will not be maximised. This is because respondents get intimidated when asked about something they consider as a highly confidential subject. In view of this, the GAS-SHI researcher had revised this question where respondents could choose the pay range that they would more conveniently reply without necessarily revealing the actual numerical figure. See Table 6.

Table 6. GAS-SHI Question Item 143.

143. What was the approximate total cash income for your household during the past 12 months?

\begin{tabular}{cc} 
Below $\$ 1000$ & From $\$ 5001$ to $\$ 6500$ \\
From $\$ 1001$ to $\$ 2500$ & From $\$ 6501$ to $\$ 8000$ \\
From $\$ 2501$ to $\$ 4000$ & From $\$ 8001$ to $\$ 10,000$ \\
From $\$ 4001$ to $\$ 5500$ & Above $\$ 10,000$ \\
\hline
\end{tabular}

GAS Question Items 148 to 151 ask about the respondents' family's financial condition in country and community. Again, the GAS-SHI researcher believes that the specificity of the terms, "country" and "community" are appropriate in a 
country GNH survey. However, in an industry survey, it would be enough to refer only to family. The question items are therefore revised and took the form as indicated in the following table, Table 7.

Table 7. GAS-SHI Question Items 144 and 145.

144. Do you consider your family to be:

\begin{tabular}{ccc}
\hline 1 & 2 & 3 \\
\hline Poorer than most families & About the same as most families & Wealthier than most families \\
\hline
\end{tabular}

145. How has your family's financial position changed over the past few years compared to other families in this country?

\begin{tabular}{cccc}
\hline 1 & 2 & 3 & 9 \\
\hline $\begin{array}{c}\text { Financial position has } \\
\text { improved less than } \\
\text { most families }\end{array}$ & $\begin{array}{c}\text { Financial position has } \\
\text { changed about the same } \\
\text { as most families }\end{array}$ & $\begin{array}{c}\text { Financial position has } \\
\text { improved more than } \\
\text { most families }\end{array}$ & Don't know \\
\hline
\end{tabular}

In another question item, the response options to GAS Question Item 155, “Are you comfortable with your current level of debt?" is incomplete for Singapore hospitality workers. Bhutan's 2016 gross domestic product per capita was reported at only US $\$ 2751.20$ which is $22 \%$ or a fraction of the world's average (Bhutan GDP per capita, 2017) [28]. Singapore's on the other hand in the same year was reported at US\$52,600.60 which is more than 400 times the world's average (specifically, $417 \%$ of the world GDP per capita average) (Singapore GDP per capita, 2017) [29]. GDP per capita is a measure of each person's income in a country on the average (The real wealth, 2012) [30]. It in turn is not also a strong gauge of how many persons owe money. Nonetheless, whether there may be fewer people indebted in Singapore, particularly those who have a source of livelihood like hospitality workers, than in Bhutan as far as the overall population or otherwise, there is a high probability that this could be so. Regardless, this question item should include a response option of "No Debt" applicable to both sets of respondents no matter in which country.

Any question item that talks about the value of other income or actual loan payment, considered a confidential and very private, should not be included. This is of the higher probability the prevailing attitude in Singapore. Thus, GAS Question Items 157 and 158 regarding house rent and loan payment do not exist anymore in the revised GAS-SHI survey.

In another question item, GAS Question Item 161 had been revised to facilitate ease to the respondent if the survey were to be self-administered. The statements were also rephrased for the same reason. See the changes between Table 8 and Table 9. 
Table 8. GAS Question Item 161.

161. Is your dwelling (house) in need of repairs?

\begin{tabular}{|c|c|c|}
\hline \multicolumn{3}{|c|}{ Please check one of the answers below } \\
\hline HRepair & No, only regular maintenance is required, painting, etc. & 1 \\
\hline & Yes, minor repairs are needed & 2 \\
\hline & $\begin{array}{c}\text { Yes, major repairs - leaking roof, defective plumbing, wiring, structural } \\
\text { repairs to walls, ceilings, roof, etc. }\end{array}$ & 3 \\
\hline
\end{tabular}

Table 9. GAS-SHI Question Item 152.

152. Is your dwelling (house) in need of repairs?

\begin{tabular}{|c|c|c|c|}
\hline & & 1 & 2 \\
\hline & & Yes & $\mathrm{No}$ \\
\hline 153a. & Regular maintenance is required, painting, etc. & & \\
\hline $153 b$. & Minor repairs are needed. & & \\
\hline 153c. & Major repairs are needed & & \\
\hline
\end{tabular}

Lastly, GAS Item 163 assures that the respondent may be a farmer, a high possibility in Bhutan but not Singapore's hospitality workers. As such, this item, along with all its sub-items, i.e., 9 variables, had been totally deleted and does not exist in the revised GAS-SHI survey.

The final output, with all the revisions on the abridged GNH version, can be downloaded from https://www.schoolnetwork-sg.com/gas-shi-questionnaire. Alternatively, request for a free copy from the author who can be contacted at the following email addresses: f.utanes@vatel.sg, fred@sdh.edu.sg, and utanesfred@gmail.com.

\section{Implications and Further Studies}

Assessing the original version of the abridged GNH version as created by Pennock and Ura (2011) [5], it is inevitable to do some changes if the instrument is used in Singapore's hospitality industry. The modifications in the abridged GNH version which had been called by the present researcher as the GAS-SHI survey had 93 needed changes out of or $29 \%$ of the 320 GAS variables. Through this innovation, the author of this present study established the suitability of the index with the revisions to the hospitality industry in Singapore that is notorious to have a low happiness score, as indicated from the review of literature. However, this observation is vague. The new version of the happiness index could pinpoint the specific dimensions or areas where the "unhappiness" might be originating from. The only issue here is which basis could a possible related study could be used as benchmark if and when the new index is used to measure the happiness of hospitality staff in Singapore.

It is then a logical next step to conduct the happiness measurement study of Singapore's hospitality sector as a spin-off inquiry. A presumed theory that 
Bhutan's original happiness measurement results or others in a few countries or situations where the GNH index was used in the past could be used to compare that further study on Singapore's hospitality sector. The next researches could also be specific to subsectors in the hospitality industry such as hotel, restaurant, or tourism. In other words, it would be worthwhile to conduct further studies on individual subsectors in expectation of more realistic and more contained outcomes.

\section{Conclusions and Significance of the Study}

The conduct and completion of this study achieved its pre-set objectives. It had assessed the suitability of the abridged GNH version in Singapore's hospitality industry and had examined the needed changes that need to be done on the abridged GNH version to suit Singapore's hospitality sector. These modifications were justified in this paper that resulted in creating the adapted version of the abridged GNH index suitable to Singapore's hospitality industry, now called by this paper's author as the GAS-SHI.

In reference to the GNH abridged survey, the sections, subsections and choice of question item responses either modified or deleted were educational attainment, envy-jealousy, bad-to-good response scale, “don't know" response in 70 variable-question items, enjoyment activity, language understanding and spoken, discrimination, enough money, and living standards. These adjustments have been adopted in now the GAS-SHI.

An ultimate test of the suitability of the GAS-SHI as a tool to measure employee wellbeing and workplace happiness will be through its actual deployment. Having used the wellbeing instrument in merely a handful of informants in the study, testing it with a greater number of participants and evaluating the results would strengthen the claim earlier underscored.

As the main output of this research, the GAS-SHI along with its inherent residual uses could be viewed by government policy makers, hospitality associations, and learning institutions as a tool to determine the real working conditions with happiness as a measurement of wellbeing. It could stimulate the inertia in coming out with government policies, best industry practices, and more appropriate academic curriculums, respectively, curb possible bullying, poor human resource management, and other causes of Singapore's marred image particularly on workers' wellbeing and workplace satisfaction in the services sector.

\section{Acknowledgements}

The researcher acknowledges the assistance of Berry Vincent Didier Emmanuel, Cristea Raphael Aurel, Morla anil Kumar, Ramni Sakshi, Reina Arfan Lie, Tran Quang Hoand, Gredia Knasih Inamasi Tokan, Mehrotra Ashutosh, and Massey Akshay (All Vatel Singapore students of the MBA in International Hotel Management programme, Batch 2017-2018) for serving as respondents in this study. 


\section{Conflicts of Interest}

The author declares no conflicts of interest regarding the publication of this paper.

\section{References}

[1] Tourism Council of Bhutan (2017) Gross National Happiness. http://www.tourism.gov.bt/about-bhutan/Gross-National-Happiness

[2] O’Neill, J. and Davis, K.D. (2010) Work Stress and Well-Being in the Hotel Industry. International Journal of Hospitality Management, 30, 385-390.

https://www.researchgate.net/publication/241694952_Work_Stress_and_Well-bein g_in_the_Hotel_Industry

[3] Veenhoven, R. (2004) Happy Life Years: A Measure of Gross National Happiness. The First International Seminar on "Operationalization of Gross National Happiness", Thimphu, 18-20 February 2004, 287-318.

https://personal.eur.nl/fsw/research/veenhoven/Pub2000s/2004b-full.pdf

[4] (2010) The Gross National Happiness Abridged Survey. Centre of Bhutan Studies Thimphu, Victoria, 1-39. http://gnh-movement.org/papers/pennock.pdf

[5] Pennock, M. and Ura, K. (2011) Gross National Happiness as a Framework for Health Impact Assessment. Environmental Impact Assessment Review, 31, 61-65. http://web.pdx.edu/ kub/publicfiles/MeasuringWellBeing/Pennock_2011\%20GNH \%20\&\%20health.pdf https://doi.org/10.1016/j.eiar.2010.04.003

[6] The Second Gross National Happiness Survey Questionnaire, April 2010. http://www.grossnationalhappiness.com/docs/2010_Results/PDF/Questionnaire201 $\underline{0 . p d f}$

[7] Hadee, I. (2015) 8 Reasons Why Retail Has High Employee Turnover. https://www.linkedin.com/pulse/8-reasons-why-retail-has-high-employee-turnover -irni-hadee

[8] Ministry of Manpower (2017) Summary Table: Labour Turnover. http://stats.mom.gov.sg/Pages/Labour-Turnover-Summary-Table.aspx

[9] Wong, I. (2018) 10 Wellness Trends to Watch in 2018. Singapore Tatler, Singapore. https://sg.asiatatler.com/style/10-wellness-trends-to-watch-in-2018

[10] Lai, L. (2017) Singaporeans Rank Low in Sense of Well-Being and Health. Straits Times.

http://www.straitstimes.com/singapore/health/singaporeans-rank-low-in-sense-ofwell-being-and-health

[11] How to Do We Measure Well-Being? (2017) The Conversation. http://theconversation.com/how-do-we-measure-well-being-70967

[12] Asian Development Bank, National Statistics Bureau (2013) Bhutan Living Standards Surveys, 2012 Report. Asian Development Bank, Mandaluyong.

[13] Briney, A. (2017) Gross National Happiness. https://www.thoughtco.com/gross-national-happiness-1434478

[14] University of Technology Sydney (2017) Isabel Sebastian Biography. https://www.uts.edu.au/staff/isabel.sebastian

[15] Boelhouwer, J. and van Campen, C. (2013) Steering towards Happiness in the Netherlands. Social Indicators Research: An International and Interdisciplinary Journal for Quality-of-Life Measurement, 114, 59-72. 
https://doi.org/10.1007/s11205-013-0383-y

[16] Brooks, A.C. (2008) Gross National Happiness: Why Happiness Matters for America-And How We Can Get More of It. Basic Books, New York.

[17] Tiefenback, T. and Kohlbacher, F. (2015) Happiness in Japan in Times of Upheaval: Empirical Evidence from the National Survey on Lifestyle Preferences. Journal of Happiness Studies, 16, 333-366. https://doi.org/10.1007/s10902-014-9512-9

[18] Tiwari, A.K. and Mutascu, M. (2015) The Relationship between Environmental Degradation and Happiness in 23 Developed Contemporary Economies. Management of Environmental Quality, 26, 301-321. https://doi.org/10.1108/MEQ-05-2014-0077

[19] Blackman, D., O’Flynn, J. and Mishra, D. (2010) Can Strategic Human Resource Management Enable Gross National Happiness? International Journal of Commerce and Management, 20, 1. https://doi.org/10.1108/10569211011076929

[20] Ministry of Manpower (2017) Total Foreign Worker Numbers. http://www.mom.gov.sg/documents-and-publications/foreign-workforce-numbers

[21] Brown, J.D. (1997) Reliability of Surveys. http://hosted.jalt.org/test/bro_2.htm

[22] Tourism Council of Bhutan (2017) Language. http://www.tourism.gov.bt/about-bhutan/language

[23] Gutman, A. and Avanzati, B. (2014) The Language Gulper. http://www.languagesgulper.com/eng/Languages_of_Bhutan.html

[24] Lee, P. (2016) English Most Common Home Language in Singapore, Bilingualism Also Up: Government Survey. The Straits Times.

http://www.straitstimes.com/singapore/english-most-common-home-language-in-s ingapore-bilingualism-also-up-government-survey

[25] Nithercott, C. (2016) Can I Live in Singapore and Only Speak English? https://www.quora.com/Can-I-live-in-Singapore-and-only-speak-English

[26] Sim, W. (2015) Singapore Signs Pact against Racial Discrimination. The Straits Times, 21 October [Online].

http://www.straitstimes.com/singapore/singapore-signs-pact-against-racial-discrimi nation

[27] Wang, J. (2017) Law against Racial Discrimination in Singapore: Notes and Cases. Eastlaw.Net. http://www.eastlaw.net/?p=459

[28] (2018) Bhutan GDP Per Capita Income. The Trading Economics. https://tradingeconomics.com/bhutan/gdp-per-capita

[29] (2018) Singapore GDP per Capita Income. The Trading Economics. https://tradingeconomics.com/singapore/gdp-per-capita

[30] (2012) The Real Wealth of Nations. The Economist. http://www.economist.com/node/21557732 